\title{
An Epidemiological Study for Assessment of Selected Lifestyle Disorders among University Students at Central Gujarat, India \\ Geetika Madan Patel ${ }^{1}$, Dhara I Zalavadiya ${ }^{1}$, Ankita Parmar ${ }^{2}$ \\ ${ }^{1}$ Associate Professor, ${ }^{2}$ Assistant Professor, Department of PSM, Parul Institute of Medical Sciences and Research, Parul University, Vadodara, Gujarat, India. \\ Correspondence : Dr. Dhara Zalavadiya, Email: dharaben.zalavadiya@paruluniversity.ac.in
}

\begin{abstract}
:
Introduction: The prevalence of overweight and obesity among children and adolescents has risen dramatically from just 4\% in 1975 to over 18\% in 2016. The risk for the non-communicable diseases increases, with increase in Body Mass Index (BMI). Objectives: To provide epidemiological insights into proportion of malnutrition in form of underweight/ overweight, hypertension and high blood sugar and to analyse the relation between anthropometric measures with Blood Pressure and Blood Sugar level among University students. Method: A cross sectional study was conducted among newly admitted college students of the university during 2018. Total 3311 students' data were collected using case-record form. Data collection included information on socio-demographic profile from students, anthropometric measurements, Blood pressure measurement and Random blood sugar (RBS) check-up. Results: The mean age was $18.7 \pm 1.2$ and $19.17 \pm 1.6$ years among male and female students, respectively. Out of 3311 students, $30.90 \%$ were in underweight category and $18.76 \%$ were in overweight or obesity category according to BMI. According to Waist-Hip ratio (WHR), 20.6\% males and 18.9\% females had substantially increased risk for metabolic complications. Around 139 (5.99\%) males and 16 (1.61\%) females were found to have high systolic blood pressure while 365 (15.7\%) males and 44 (4.4\%) females were in high diastolic blood pressure category. Around $1.06 \%$ had RBS $>140 \mathrm{mg} / \mathrm{dl}$. There was positive correlation and statistically significant association between BMI and WHR with high blood pressure. Conclusions: High prevalence of underweight, overweight and obesity, high WHR, high blood pressure among youth population demands early screening and intervention to prevent morbidity and mortality in later life.
\end{abstract}

Key words: Lifestyle, Non-communicable diseases, Obesity, Overweight

\section{Introduction:}

Undernutrition coexisting with overweight and obesity is significant health challenge many countries. In India, the share of underweight adults is the highest globally, even as the country experiences an ongoing rise in overweight/obesity due to urbanization, improved economic conditions, the prevalence of sedentary lifestyles, and dietary changes. ${ }^{[1]}$
Non-Communicable diseases kill 41 million people each year globally. In terms of attributable deaths, the leading risk factor globally is high blood pressure to which $19 \%$ of global deaths are attributed, followed by overweight/obesity and raised blood glucose..$^{[2]}$ Two thirds of premature deaths in adults are associated with conditions and behaviors of childhood and youth. ${ }^{[3]}$

\begin{tabular}{|c|c|c|}
\hline Quick Response Code & Access this article online & How to cite this article: \\
\hline \multirow{2}{*}{ 口ifing } & $\begin{array}{l}\text { Website : } \\
\text { www.healthlinejournal.org }\end{array}$ & \multirow{2}{*}{$\begin{array}{l}\text { Patel G, Zalavadiya D, Parmar A. An epidemiological } \\
\text { study for assessment of selected lifestyle disorders } \\
\text { among University students at Central Gujarat, India. } \\
\text { Healthline. } 2021 ; 12(2): 21-27 \text {. }\end{array}$} \\
\hline & $\begin{array}{l}\text { DOI : } \\
\text { 10.51957/Healthline_211_2021 }\end{array}$ & \\
\hline
\end{tabular}


The prevalence of hypertension among adolescents is $4.5 \%$. By the age of 15 , more than $25 \%$ of obese adolescents have early signs of diabetes. Among obese youth, 70\% have at least one risk factor for cardiovascular disease by the age of $20 .^{[4]}$ Quantification of elevated risk for exposed groups of individuals is important to inform decision making on individual health; as well as important input into any national or global strategy to improve population health and make progress. ${ }^{[5]}$

The present study was conducted with the objective of providing epidemiological insights in to proportion of malnutrition in form of under nutrition/ obesity, high blood pressure, high blood sugar level and to analyze the relation between anthropometric measures with Blood pressure and blood sugar level among University students. The university is Gujarat's one of the leading private university covering diploma, undergraduate and post graduate programs including around 21 faculties like medicine, pharmacy, engineering, arts, commerce, management and many more.

\section{Method:}

It was a cross sectional study including 4000 university students enrolled in the first year at the university during 2018 academic year. Schedule of health checkup was prepared for each and every faculty in advance to ensure quality of checkup and maximum attendance of the students, after discussion with respective principles. Per day maximum 60 students were scheduled. If absent on particular day, students were allowed to join the next batch of their college. At the end of data collection, 3328 students participated voluntarily in the checkup. After data cleaning 3311 student's data was available for analysis. As the study invited all the $1^{\text {st }}$ year students enrolled during 2018-year, sampling was not required.

Inclusion-exclusion criteria : All the students enrolled for 1st year in the university, gave written consent to take part in the study were included in the health checkup. Students who are not in $1^{\text {st }}$ academic year, not ready to give consent, drop outs, having obvious skeletal deformities were excluded from the study.

Permission was taken from institutional ethicl committee prior to the data collection procedure. Written consent was taken from the participants before data collection. Data were collected using case record form which included structured questionnaire to collect information on socio-demographic profile, anthropometry and clinical profile including blood pressure and Random blood sugar (RBS). Sociodemographic profile was filled up by students after proper instruction under supervision of respective faculties/teachers.

Medical checkup part included measurement of Blood Pressure, Random blood sugar and anthropometric measurement. Anthropometric measurements, Blood pressure measurement and RBS checkup were done by trained health staff and recorded in the form. Trained health staff included team of fixed medical officers, staff nurse and laboratory technician. Anthropometric measurements included Height, Weight, Hip circumference and Waist circumference. Instruments were calibrated before use. Height was measured to the nearest 0.1 centimeter using stadiometer, and weight was measured to the nearest 0.1 kilogram using a portable scale. Both height and weight were measured with shoes, coats, and other heavy outerwear removed. Body Mass Index (BMI) was calculated as the ratio of weight to height squared $\left(\mathrm{kg} / \mathrm{m}^{2}\right)$. BMI values were categorized according to WHO classification. ${ }^{[6]}$ Waist and hip circumference were measured according to guideline given in Waist Circumference and Waist-Hip Ratio Report of a WHO. Data were categorized according to WHO cut-off points for risk of metabolic complications. ${ }^{[7]}$

Blood pressure was measured using manual sphygmomanometer by auscultatory method. If the student's systolic and diastolic blood pressure were normal, blood pressure was recorded. If the first measurement was elevated, the blood pressure was 
retaken after rest for 10 minutes. The process was repeated one more time if the blood pressure remained elevated and students were also referred to medicine department for further investigation and management. Blood pressure was categorized according to the Joint National committee (JNC-7) ${ }^{[8]}$ classifications. RBS was measured using glucometer and results were recorded in $\mathrm{mg} / \mathrm{dl}$. Similarly, students those who had high RBS ( $\geq 200 \mathrm{mg} / \mathrm{dl}$ ) value at the time of study were also referred to medicine department. A blood glucose level between 79 and $140 \mathrm{mg} / \mathrm{dl}, 140$ and $200 \mathrm{mg} / \mathrm{dl}$ and more than 200 $\mathrm{mg} / \mathrm{dl}$ was considered normal, prediabetes and diabetes respectively according to American Diabetes Association Criteria. ${ }^{[9]}$

Data entry and analysis : Data entry was done in university web portal from case record forms by trained health staff. Excel sheet was assessed from university web portal and used for data analysis. Proportion and frequency for underweight, obesity, hypertension and risk for diabetes was calculated using standard references. Correlation and association were also checked between different anthropometric parameters and blood pressure and diabetes risk.

\section{Results:}

Around 3311 students' health check-up data were available for analysis. Out of them 2319 (70.04\%) were males and 992 (29.96\%) were females. The mean age with standard deviation was $18.7 \pm 1.2$ and $19.17 \pm 1.6$ years among male and female students, respectively. Mean values for height, weight, BMI, Hip and waist circumference measurements are more in males as compared to females except mean RBS. There was significant difference in mean values of different measurements among males and female students. (Table1)

Classification according to BMI\& WHR: Out of 3311 students, 621 (18.76\%) had BMI $\geq 25.0 \mathrm{~kg} / \mathrm{m}^{2}$ and among them 176 (5.31\%) were obese according to WHO classification. Around 665 (28.68\%) males were underweight and 358 (36.09\%) females were in underweight category (Table 2). Undernutrition was statistically significant among females as compared to males $(\mathrm{p}<0.0001)$ while overweight and obesity is statistically significant among males (19.75\%) as compared to females $(16.42 \%)(\mathrm{p}=0.0278)$.

Out of 3311 study subjects, 664 (20\%) students were found to be substantially increased risk for metabolic complications as per their WHR measurements. According to waist circumference

Table 1: Mean values of basic measurements in male and female students

\begin{tabular}{|c|c|c|c|c|}
\hline Variable & Total & Male & Female & $\begin{array}{c}\text { p-value } \\
\text { (Independent } \\
\text { sample t-test) }\end{array}$ \\
\hline Weight $(\mathrm{kg})$ & $57.57 \pm 13.90$ & $60.57 \pm 13.63$ & $50.54 \pm 11.86$ & $<0.0001$ \\
\hline Height $(\mathrm{cm})$ & $164.47 \pm 9.12$ & $168.17 \pm 7.27$ & $155.81 \pm 6.85$ & $<0.0001$ \\
\hline BMI $\left(\mathrm{kg} / \mathrm{m}^{2}\right)$ & $21.25 \pm 4.93$ & $21.44 \pm 5.00$ & $20.82 \pm 4.72$ & 0.0009 \\
\hline Waist circumference $(\mathrm{cm})$ & $77.85 \pm 12.78$ & $80.28 \pm 12.59$ & $72.19 \pm 11.33$ & $<0.0001$ \\
\hline Hip circumference $(\mathrm{cm})$ & $93.26 \pm 10.47$ & $93.87 \pm 10.44$ & $91.84 \pm 10.40$ & $<0.0001$ \\
\hline WHR & $0.83 \pm 0.099$ & $0.86 \pm 0.095$ & $0.79 \pm 0.09$ & $<0.0001$ \\
\hline SBP $(\mathrm{mmHg})$ & $116.84 \pm 11.7$ & $119.26 \pm 11.32$ & $111.19 \pm 10.56$ & $<0.0001$ \\
\hline DBP $(\mathrm{mmHg})$ & $76.72 \pm 8.08$ & $78.02 \pm 7.99$ & $73.70 \pm 7.49$ & $<0.0001$ \\
\hline RBS $(\mathrm{mg} / \mathrm{dl})$ & $93.1 \pm 15.3$ & $91.49 \pm 14.37$ & $96.78 \pm 16.77$ & $<0.0001$ \\
\hline
\end{tabular}


Table 2: Classification of students according to BMI

\begin{tabular}{|c|c|c|c|c|}
\hline Classification & BMI (kg/m2) & Total (\%) & Male (\%) & Female (\%) \\
\hline Underweight & $<18.50$ & $1023(30.90)$ & $665(28.68)$ & $358(36.09)$ \\
\hline Normal weight & $18.50-24.99$ & $1667(50.35)$ & $1196(51.57)$ & $471(47.48)$ \\
\hline Pre-obese & $25.00-29.99$ & $445(13.44)$ & $330(14.23)$ & $115(11.59)$ \\
\hline Obese class-I & $30.00-34.99$ & $131(3.96)$ & $101(4.36)$ & $30(3.02)$ \\
\hline Obese class-II & $35.00-39.99$ & $35(1.06)$ & $19(0.82)$ & $16(1.61)$ \\
\hline Obese class-III & $\geq 40.0$ & $10(0.30)$ & $8(0.34)$ & $2(0.20)$ \\
\hline \multicolumn{2}{|c|}{ Total } & $\mathbf{3 3 1 1}$ & $\mathbf{2 3 1 9}$ & $\mathbf{9 9 2}$ \\
\hline
\end{tabular}

Table 3: Classification of students according to waist circumference, WHR and risk for metabolic complication as per WHO classification

\begin{tabular}{|c|c|c|c|c|c|}
\hline & $\begin{array}{c}\text { Cut-off } \\
\text { points (M) }\end{array}$ & Males (\%) & $\begin{array}{c}\text { Cut-off } \\
\text { points (F) }\end{array}$ & Female (\%) & $\begin{array}{c}\text { Risk of metabolic } \\
\text { complication }\end{array}$ \\
\hline Waist & $>94 \mathrm{~cm}$ & $166(7.2)$ & $>80 \mathrm{~cm}$ & $140(14.1)$ & Increased \\
\hline Waist & $>102 \mathrm{~cm}$ & $87(3.8)$ & $>88 \mathrm{~cm}$ & $76(7.7)$ & Substantially increased \\
\hline WHR & $>0.90 \mathrm{~cm}$ & $477(20.6)$ & $>0.85 \mathrm{~cm}$ & $187(18.9)$ & Substantially increased \\
\hline Total & & $\mathbf{2 3 1 9}$ & & $\mathbf{9 9 2}$ & \\
\hline
\end{tabular}

Table 4: Classification of students according to Blood pressure

\begin{tabular}{|c|c|c|c|c|c|c|c|c|}
\hline Category & $\begin{array}{c}\text { SBP } \\
(\mathbf{m m H g})\end{array}$ & $\begin{array}{c}\text { Total } \\
(\mathbf{\%})\end{array}$ & $\begin{array}{c}\text { Male } \\
\mathbf{( \% )}\end{array}$ & $\begin{array}{c}\text { Female } \\
\mathbf{( \% )}\end{array}$ & $\begin{array}{c}\text { DBP } \\
(\mathbf{m m H g})\end{array}$ & $\begin{array}{c}\text { Total } \\
(\mathbf{\%})\end{array}$ & $\begin{array}{c}\text { Male } \\
\mathbf{( \% )}\end{array}$ & $\begin{array}{c}\text { Female } \\
\mathbf{( \% )}\end{array}$ \\
\hline Optimal & $<120$ & $\begin{array}{c}1652 \\
(49.89)\end{array}$ & $\begin{array}{c}946 \\
(40.79)\end{array}$ & $\begin{array}{c}706 \\
(71.17)\end{array}$ & $<80$ & $\begin{array}{c}1544 \\
(46.63)\end{array}$ & $\begin{array}{c}898 \\
(38.72)\end{array}$ & $\begin{array}{c}646 \\
(65.12)\end{array}$ \\
\hline $\begin{array}{c}\text { Pre } \\
\text { hypertension }\end{array}$ & $120-139$ & $\begin{array}{c}1504 \\
(45.42)\end{array}$ & $\begin{array}{c}1234 \\
(53.21)\end{array}$ & $\begin{array}{c}270 \\
(27.21)\end{array}$ & $80-89$ & $\begin{array}{c}1358 \\
(41.01)\end{array}$ & $\begin{array}{c}1056 \\
(45.54)\end{array}$ & $\begin{array}{c}302 \\
(30.44)\end{array}$ \\
\hline Stage-1 HT & $140-159$ & $\begin{array}{c}132 \\
(3.99)\end{array}$ & $\begin{array}{c}118 \\
(5.09)\end{array}$ & $\begin{array}{c}14 \\
(1.41)\end{array}$ & $90-99$ & $\begin{array}{c}363 \\
(10.96)\end{array}$ & $\begin{array}{c}332 \\
(14.32)\end{array}$ & $\begin{array}{c}31 \\
(3.13)\end{array}$ \\
\hline Stage-2 HT & $\geq 160$ & 23 & 21 & 2 & 2100 & 46 & 33 & 13 \\
$(0.69)$ & $(0.91)$ & $(0.20)$ & $(1.39)$ & $(1.42)$ & $(1.31)$ \\
\hline Total & & 3311 & 2319 & 992 & & 3311 & 2319 & 992 \\
\hline
\end{tabular}

measures,163 (4.9\%) students were found to be substantially increased risk for metabolic complications (Table 3).

Classification according to Blood pressure\& RBS: According to JNC-7 blood pressure categorization, around 139 (5.99\%) males and 16 (1.61\%) females were found to have high systolic blood pressure (SBP) while 365 (15.7\%) males and 44 (4.4\%) females were in high diastolic blood pressure (DBP) category (Table 4). Frequency of high blood pressure was higher among males as compared to female students $(\mathrm{p}<0.0001)$.

Out of 3311 students, 373 (11.3\%) students had RBS value less than 79 md/dl. Around 2903 (87.7\%) had RBS values between 79 to $140 \mathrm{mg} / \mathrm{dl}$ and 35 (1.06\%) had RBS more than $140 \mathrm{mg} / \mathrm{dl}$. There was no 
significant difference for being prediabetics (RBS $>141)$ among males and females $(\mathrm{p}=0.06)$. Only 2 students were found to have RBS $>200 \mathrm{mg} / \mathrm{dl}$.

Obesity, BP and RBS (correlation): There was positive and significant correlation of SBP with Waist circumference $(\mathrm{r}=0.32)$, WHR $(\mathrm{r}=0.16)$ and BMI $(\mathrm{r}=0.29)(\mathrm{p}<0.0001)$. Similarly, DBP was positively and significantly corelated with Waist circumference $(r=0.27)$, WHR $(r=0.12)$ and BMI $(r=0.26)$ $(\mathrm{p}<0.0001)$. RBS values were weakly correlated with BMI ( $\mathrm{r}=0.052)$, waist $(\mathrm{r}=0.007)$, WHR $(\mathrm{r}=-0.0016)$, SBP $(r=0.06)$ and DBP $(r=0.04)$.

Obesity, BP and RBS (Association): There was significant association between $\mathrm{BMI} \geq 25.0 \mathrm{~kg} / \mathrm{m} 2$ and hypertension (SBP $>139 \mathrm{mmHg}$ and or $\mathrm{DBP}>89$ mmHg) (Chi-square=129.6, p $<0.0001$ ). Similarly, there was significant association between Obesity according to waist circumference (male $>95 \mathrm{~cm}$, female $>80 \mathrm{~cm}$ ) and Hypertension (Chi-square $=81.2$, $\mathrm{p}<0.0001$ ). Obesity according to WHR (male $>0.90$ and female $>0.85$ ) and Hypertension also showed significant association (Chi-square $=26.8, \mathrm{p}<0.0001$ ).

Being high risk for diabetes (RBS $>140 \mathrm{mg} / \mathrm{dl}$ ) did not show significant association with any of the obesity criteria like WHR (Chi-square $=1.1, \mathrm{P}=0.29$ ) or BMI (Chi-square $=1.67, p=0.19$ ). Similarly, there was no association between hypertension and being high risk for diabetes (Chi-square $=0.86, \mathrm{p}=0.35$ ).

\section{Discussion:}

In present study, Prevalence of underweight was $30.90 \%$. According to National Nutrition Monitoring Bureau (NNMB) report, only two-thirds of the recommended calories are consumed by adolescent boys and girls, which result in high prevalence of undernutrition. $^{[10]}$ Barrier function of body is compromised by undernutrition, which results in lower immunity, easy entry and growth of pathogens in the body. Infection accelerated by undernutrition again causes changes in dietary intake, food absorption and losses of endogenous nutrients. That ultimately result in malnutrition infection vicious cycle.$^{[11]}$ Underweight was significantly more frequent among females as compared to males in present study findings. Again, higher rate of undernutrition among girls increases morbidity and mortality associated with pregnancy and child birth. That leads to the intergenerational cycle of malnutrition. ${ }^{[12]}$

On the other hand, Prevalence of overweight and Obesity was $13.44 \%$ and $5.32 \%$ in present study. Similar result was reported as $15.1 \%$ overweight and $5.2 \%$ obesity in University Students from 22 Countries. ${ }^{[13]}$ Overweight and obesity was significantly higher among males (19.75\%) as compared to females (16.42\%). Number of studies from Asia also shows that male gender is more associated with overweightand obesity. ${ }^{[13-16]}$

Large number of students, $45.42 \%$ were in Pre hypertension category, $4.68 \%$ had high SBP and $12.35 \%$ had high DBP in present study. Frequency of high blood pressure was higher among males as compared to female students. NFHS-4 data also shows that hypertension is more prevalent among adult males $(13.6 \%)$ as compared to adult females $(8.8 \%) \cdot{ }^{[17]}$ Blood pressure difference among male and females are detectable during adolescence and persist through adulthood. In all ethnic groups, men tend to have higher mean blood pressure than women. ${ }^{[18]}$ Among premenopausal females, lower level of blood pressure have been explained by protective effect of estrogen and other life style habits like smoking and alcohol. ${ }^{[19]}$

Data from Framingham Heart Study, which followed study subjects for 30 years, showed that SBP shows linear increase between the ages of 30 and 84 years or over. The Framingham Heart Study also showed that cardiovascular risk is continuously, positively and independently associated with rising Blood pressure. ${ }^{[20]}$ Thus, students in prehypertension category today may be in hypertension category in later life with increased risk of cardiovascular complications.

There was positive and significant correlation between Waist circumference, WHR and BMI with SBP and DBP blood pressure values. There was 
significant association between high BMI and HT, high Waist circumference and HT and high WHR and HT in present study. Similar relationship has been documented in various studies between anthropometry and Blood pressure. ${ }^{[21-24]}$ RBS values were weakly correlated with obesity in terms of BMI and WHR. Similar result is documented by study done in rural area of Telangana state. ${ }^{[25]}$

\section{Conclusion:}

According to WHR, 20.6\% males and 18.9\% females had substantially increased risk for metabolic complications. Around $18.76 \%$ had BMI $\geq$ $25 \mathrm{~kg} / \mathrm{m}^{2}$ and $57.77 \%$ were in Pre hypertension or hypertension category. Out of 3311 subjects, 1.06\% had RBS>140 mg/dl. All these students are at high risk for future NCDs and chronic diseases. On the other hand, high number of underweight (30.90\%) students are at risk of morbidity and mortality associated with undernutrition. There was positive correlation between BMI, WHR and high blood pressure.

Data point outs the opportunity to educate youth and their parents at early stage of life. Young adult is an important age-group and any corrective health measures will help not only improve their individual health but could also have a lasting impact in the community and also towards breaking a vicious cycle of intergenerational malnutrition and preventing/ delaying lifestyle associated morbidities/mortality later in life.

\section{Declaration:}

Funding: Nil

\section{Conflict of Interest: Nil}

\section{References:}

1. The double burden of malnutrition among adults in India: evidence from the National Family Health Survey-4 (2015-16). Epidemiol Heal. 2019;41.

2. World Health Organization. Noncommunicable diseases. Available from: https://www.who.int/en/news-room/factsheets/detail/noncommunicable-diseases

3. World Health Organization. NCD and Youth;WHO Global Coordination Mechanism on the Prevention and Control of NCDs.
Available from: https://www.who.int/global-coordinationmechanism/ncd-themes/ncd-and-youth/en/

4. Non-Communicable Diseases and Adolescents; An opportunity for action, Young Health Programme- AstraZeneca's global community investment programme. 2014. Available from:https://www.younghealthprogrammeyhp.com/content/ dam/young-health/Resources/ProgrammeReports/NonCommunicable-Diseases-and-Adolescents-8211-AnOpportunity-for-Action.pdf

5. Global, regional, and national comparative risk assessment of 79 behavioural, environmental and occupational, and metabolic risks or clusters of risks, 1990-2015: a systematic analysis for the Global Burden of Disease Study 2015. Lancet. 2016;388(10053):P1659-1724.

6. World Health Organization. Body mass index - BMI.Available from: http://www.euro.who.int/en/health-topics/diseaseprevention/nutrition/a-healthy-lifestyle/body-mass-index-bmi

7. Waist circumference and WHR, Report of WHO expert consultation. 2008. Available from:http://apps.who.int/ iris/bitstream/handle/ 10665/44583/9789241501491_eng.pdf;jsessionid=02F0368249D 156F27E2FD862C3FA9491? sequence $=1$

8. The Seventh Report of the Joint National Committee on Prevention, Detection, Evaluation, and Treatment of High Blood Pressure. 2004.

9. American Diabetes Association; Standards of Medical Care in Diabetes. Diabetes Care. 2017;40(1).

10. National Nutrition Monitoring Bureau (India). India Rural Survey of Diet and Nutritional Status. 2006.

11. Calder PC, Jackson AA. Undernutrition, infection and immune function. Nutr Res Rev. 2000 Jun;13(1):3-29.

12. World Health Organization. Adolescent Nutrition; A review of the situation in selected South-East Asian countries. WHO Regional Office for South-East Asia. Available from: https://apps.who.int/iris/handle/10665/204764

13. Peltzer K, Pengpid S, Samuels TA, Özcan NK, Mantilla C, Rahamefy $\mathrm{OH}$, et al. Prevalence of overweight/obesity and its associated factors among university students from 22 countries. Int J Environ Res Public Health. 2014 Jul;11(7):7425-41.

14. Boo NY, Chia GJQ, Wong LC, Chew RM, Chong W, Loo RCN. The prevalence of obesity among clinical students in a Malaysian medical school. Singapore Med J. 2010 Feb;51(2):126-32.

15. Banwell C, Lim L, Seubsman SA, Bain C, Dixon J, Sleigh A. Body mass index and health-related behaviours in a national cohort of 87,134 Thai open university students. J Epidemiol Community Health. 2009 May;63(5):366-72.

16. Jain S, Pant B, Chopra H, Tiwari R. Obesity among adolescents of affluent public schools in Meerut. Indian J Public Health [Internet]. 2010 Jul 1;54(3):158-60. Available from: https://www.ijph.in/article.asp?issn=0019-557X

17. International Institute for Population Sciences; Mumbai. National Family Health Survey (NFHS-4): India fact sheet. 2016. 
18. Stamler J, Stamler R, Riedlinger WF, Algera G, Roberts RH. Hypertension screening of 1 million Americans. Community Hypertension Evaluation Clinic (CHEC) program, 1973 through 1975. JAMA. 1976 May;235(21):2299-306.

19. Mendelsohn ME, Karas RH. The protective effects of estrogen on the cardiovascular system. N Engl J Med. 1999 Jun;340(23):1801-11.

20. Franklin SS. Ageing and hypertension: the assessment of blood pressure indices in predicting coronary heart disease. J Hypertens Suppl Off J IntSoc Hypertens. 1999 Dec;17(5):S29-36.

21. Shanthirani CS, Pradeepa R, Deepa R, Premalatha G, Saroja R, Mohan V. Prevalence and risk factors of hypertension in a selected South Indian population--the Chennai Urban Population Study. J Assoc Physicians India. 2003 Jan;51:20-7.
22. Bose K, Ghosh A, Roy S, Gangopadhyay S. Blood pressure and waist circumference: an empirical study of the effects of waist circumference on blood pressure among Bengalee male jute mill workers of Belur, West Bengal, India. J Physiol Anthropol Appl Human Sci. 2003 Jul;22(4):169-73.

23. Doll S, Paccaud F, Bovet P, Burnier M, Wietlisbach V. Body mass index, abdominal adiposity and blood pressure: consistency of their association across developing and developed countries. Int J Obes Relat Metab Disord. 2002 Jan;26(1):48-57.

24. Patil R, Garg B. Prevalence of hypertension and variation in blood pressure among school children in rural area of Wardha. Indian J Public Health [Internet]. 2014 Apr 1;58(2):78-83. Available from:https://www.ijph.in/article.asp?issn=0019-557X

25. T Kamalaja, K Rajeswari. Correlation of body mass index to random blood glucose levels of rural population. Pharma Innov J. 2020;9(3):171-4. 